\title{
Antun Šundalić
}

\section{Selo iz autentičnosti u neprepoznatljivost Prilog sociološkom istraživanju ruralnosti Slavonije i Baranje}

\author{
Sveučilište Josipa Jurja Strossmayera u Osijeku, Ekonomski fakultet u Osijeku, \\ Osijek, 2010., 271 str.
}

Dr. sc. Antun Šundalić redoviti je profesor na Ekonomskom fakultetu Sveučilišta J. J. Strossmayera u Osijeku gdje predaje sociologiju i uvod u metodologiju znanstvenog rada. Knjiga Selo iz autentičnosti u neprepoznatljivost četvrta je autorova samostalna knjiga, a nastala je u sklopu projekta MZOŠ RH Posttranzicijski identitet ruralnog prostora Slavonije i Baranje. Knjiga se sastoji od sedam poglavlja, odnosno od dvije cjeline, prve u kojoj autor donosi teorijsku podlogu dvaju istraživanja koja slijede u drugom dijelu knjige.

Antun Šundalić u svojoj knjizi Selo iz autentičnosti u neprepoznatljivost prikazuje trenutno stanje sela u Slavoniji i Baranji, ruralnom prostoru koji čini agrarno najplodniji dio Hrvatske i na kojem živi oko milijun stanovnika. Konstatirajući kako se Slavoniji i Baranji tijekom tranzicijskog razdoblja, u kojem se našlo hrvatsko društvo, dogodila periferizacija, uzroci koje su "geografski smještaj i prometna nepovezanost, prostorna udaljenost od političkog centra odlučivanja, marginaliziranost dominirajuće djelatnosti ovoga kraja (poljoprivrede), loše privatizacijske odluke, te ratna sudbina s velikim ljudskim i materijalnim gubicima", Šundalić zaključuje sljedeće: "deagrarizacija i depopulacija sela, kao i senilizacija seoskog stanovništva nisu učinci intenzivne industrijalizacije i modernizacije, oni su posljedica nerazvoja i pasivizacije prirodnih resursa i na njima zasnovanoj glavnoj djelatnosti - poljoprivredi". Promjene koje na globalnoj razini donosi kapitalistički svijet pod krovnim procesom globalizacije zapravo su one koje možemo smatrati odgovornima za stanje u primarnoj gospodarskoj djelatnosti koja proizvodi ključni resurs za opstanak svakog društva, smatra autor.

Antun Šundalić u prvom dijelu svoje knjige Selo iz autentičnosti u neprepoznatljivost opisuje upravo uzroke i razloge periferizacije, deruralizacije, depopulacije, zakašnjele modernizacije, koja opet dolazi kao modernizacija socijalističkog karaktera te, napokon prelaska na slobodno tržište, koje sa sobom donosi mukotrpno razdoblje tranzicije u cijeloj Hrvatskoj pa tako i u Slavoniji i Baranji. Poljoprivreda 
je tijekom tranzicijskog razdoblja postala "sredstvo nove forme stare ekspanzije - ekspanzije u socijalni prostor pomoću kontroliranja izvora hrane", odnosno poljoprivreda je postala onakvom kakvu je kapitalističko natjecateljsko tržište oblikovalo. Iz poljoprivrede se u suvremenom svijetu gubi koncept prirode kao radionice i laboratorija seljaka koja je određivala ritam rada i odmora, cikluse rasta i sazrijevanja. "Nova je stvarnost seljaku oduzela prirodu, Boga također. Seljaka je 'raseljačila', poljoprivredu je industrijalizirala, i tržišno odredila niskoprofitabilnošću." Dodatne probleme u razvoju sela i poljoprivrede u Hrvatskoj Šundalić vidi u nejednakoj razvijenosti regija. Uzroke vidi u povijesnim zbivanjima, ekonomiji, prometnoj (ne)povezanosti, demografskim promjenama, i naravno, globalizacijskim procesima koji su "omogućeni informatičkom tehnologijom, a poticani gospodarskim i političkim interesima, učinili pojedine regije pasivnijima od drugih, u jedne su locirali 'pamet', a druge lišili potonje." Slavonija i Baranja su, smatra autor, upravo prostori koje navedeni negativni utjecaji nisu mimoišli. Premda Antun Šundalić navodi kako je sve više seoskog stanovništva koje posjeduje kuću s okućnicom, a sve manje onih koji imaju kuću sa zemljišnim posjedom na kojem rade i od kojeg žive, možemo na to gledati s pozitivne strane i zaključiti kako je na pomolu smanjenje deruralizacije određenih ruralnih prostora Hrvatske kao što su to Slavonija i Baranja, iako se čini da je deagrarizacija još uvijek dominantan proces s kojim se bori hrvatsko selo. Možda ce koncept obiteljskih poljoprivrednih gospodarstava, o kojima autor govori u drugom dijelu knjige pripomoći opstanku poljoprivrede, odnosno malih poljoprivrednih gospodarstava. Autor zaključuje kako bavljenje selom i seljaštvom više ne znači bavljenje seljačkim društvom, naprotiv, riječ je globalnom društvu u kojem je priroda, slijedom industrijalizacije i (okašnjele) modernizacije prestala biti gospodarica seoskog života. Ruralna je sociologija, prema tome, prestala biti posebna sociologija koja se bavi selom i seljaštvom, ona je danas usmjerena na globalno društvo. Drugim riječima, "Sociologija se našla u novom socijalnom kontekstu koji naglašeno povezuje moderno društvo i prirodni okoliš. Stanje društva i stanje okoliša neodvojive su teme, posebice u fokusiranju nove dihotomije lokalno-globalno kojom su zamijenjene stare dihotomije ruralnourbano, tradicijsko-moderno."

Drugo poglavlje prvog dijela knjige Selo iz autentičnosti u neprepoznatljivost pod naslovom Selo $i$ seljak prikazuje transformaciju sela i seljaka suvremenog doba. Tako je selo danas, prema mišljenu autora, "ni po čemu specifično naselje pojedinaca zatvorenih u obiteljske krugove, različitih profesija i navika, različitih ambicija i ciljeva". "Ruralnost je time sve manje određena usmjerenošću na prirodu, a sve više uvjetovanošću tržištem i tehnologijom." Seljak je doživio transformaciju u poljoprivrednika, koji je pak proizvod tržišne orijentacije. Industrijsko društvo XX. stoljeća selo podređuje gradu a poljoprivredu industriji zaključuje Šundalić.

Treće poglavlje diskutira o ruralnom prostoru u Hrvatskoj s posebnim osvrtom na ruralni prostor Slavonije i Baranje. Autor naglašava važnost postmoderne ekološke paradigme koja nastoji na prilagođavanju čovjeka, tehnologije ali i kulture uopće prirodi. Međutim, smatra kako je potraga za romantikom seoskog života kao odmora od gradske vreve zapravo ništa drugo do novi oblik dominirajuće orijentacije 
kulturocentrizma. Ruralni prostor u Hrvatskoj ne smije biti zanemaren upravo zbog činjenice da čini oko 90\% našeg teritorija. Premda se postotak seoskog stanovništva u odnosu na prijašnje popise stanovništva smanjuje (2005. godine iznosi 31\%), sela su, naravno, brojnija od gradova (124 grada i 6635 sela i zaselaka). Prema tome, naglašava autor, sela su i dalje jedina mjesta gdje je moguća poljoprivreda kao životno zanimanje ali, na žalost, sve manje kao životna djelatnost, u smislu postizanja punog životnog smisla. Seljak, dakle, sve više postaje parcijalni proizvođač, nalik industrijskom radniku. Pitajući se je li modernizacija uistinu i revitalizacija ruralnog prostora autor ističe kako je revitalizacije mnogo više od retradicionalizacije, a bitnim smatra i nužnost "razvojnog sklada", misleći pri tome na ravnomjeran razvitak.

Drugi dio knjige, kao što je već napomenuto, donosi analizu i interpretaciju dvaju empirijskih istraživanja. Prvo, pod naslovom Novi identitet ruralnog prostora obavljeno je 2008. godine a za cilj je imalo ustanoviti koja su to nova obilježja života u ruralnom prostoru Slavonije i Baranje, te kakav je njihov odnos prema tradicijskom sadržajima koji još žive, kako u empiriji, tako i u memoriji žitelja ovih prostora. Dugo istraživanje, Modernizacija poljoprivrede $i$ novi identitet seljaka, provedeno u veljači 2010. godine, imalo je za cilj dopuniti nedostatak prvog istraživanja i to tako što je kao središnju temu postavilo odnos seljaka prema modernoj tehnologiji proizvodnje u poljoprivredi na obiteljskim poljoprivrednim gospodarstvima Slavonije i Baranje. Dakle, peto i šesto poglavlje knjige posvećeni su rezultatima navedenih istraživanja. Prvo je istraživanje, čiji su rezultati prikazani u petom poglavlju usmjereno je na percepciju sela i seoskog u očima ispitanika, žitelja prostora Slavonije i Baranje. Polazi se od poimanja tradicije, zajedništva i solidarnosti, preko prirodnosti okruženja i infrastrukturne opremljenosti, da bi završilo s demografskim promjenama i viđenjem budućnosti regije. Autor ovdje zaključuje kako se "seosko" u selu Slavonije i Baranje najviše zadržalo u svijesti Slavonaca i Baranjaca, "svijesti koja time nije zapreka razvoju i modernizaciji”. Drugo je istraživanje, prikazano u šestom poglavlju knjige, bilo usmjereno na istraživanje fenomena informatizacije ruralnog prostora, gdje je bilo bitno istražiti koliko je i kako slavonsko-baranjski seljak doživio fenomen informacijske revolucije, informatizacije ruralnog prostora i osnovne djelatnosti sela - poljoprivrede.

Zaključak koji Šundalić izvodi iz navedenog istraživanja je sljedeći: "Obrazovanje za novu tehnologiju proizvodnje kao i za nove poljoprivredne kulture, ipak je jedini put prema konkurentnosti hrvatske poljoprivrede i bogaćenja sela".

Na posljetku, Antun Šundalić je, istina, s nostalgičnim prizvukom govorio o selu kakvo je nekad bilo ali i kritizirao ono u što se suvremeno selo danas pretvara. On detaljno opisuje povijesni tijek (ne)razvitka sela, ne samo sela u Slavoniji i Baranji, već Hrvatskog sela uopće, uz to, dvama provedenim istraživanjima uistinu doprinosi razumijevanju trenutnog stanja sela Slavonije i Baranje. Osim toga, u svojoj je knjizi Selo iz autentičnosti u neprepoznatljivost došao do dva bitna zaključka: 1 . "Dogodi li se nestajanje identiteta sela, dakako, i grad će se izgubiti u svom prepoznatljivom odmaku od sela. (...) Treba li to shvaćati kao mogući gubitak ili kao 
nestajanje ograničenja, pitanje je iz čijeg se odgovora može vidjeti određeno shvaćanje razvoja - razvoj kao promjene koje uklanjaju razlike i posebnosti, ili razvoj kao zadržavanje i razvijanje posebnosti."; 2. Ovaj drugi razvoj koji podrazumijeva zadržavanje i razvoj posebnosti bio bi primjereniji očekivanjima i razumijevanju promjena stanovnika ruralnih područja. Toj tezi u prilog idu rezultati istraživanja u ovoj knjizi - "žitelji Slavonije i Baranje još uvijek se određuju pripadanjem ruralnoj regiji, i dalje vjeruju da je poljoprivreda ne samo identifikator regije već i djelatnost koja može jamčiti razvoj regije. U njihovoj je svijesti još uvijek vrlo jaka memorija sela kakvo je nekada bilo (...)". Dakle, svojevrsnim "romantičarskim pristupom selu i regiji Slavonci i Baranjci su u postmoderni, oni nisu za isključiva rješenja i odgovore već, za više mogućnosti: i selo kakvog se sjećamo i modernizaciju sela; selo drugačije od grada i selo sa svim životno potrebnim sadržajima”.

Integralna održivost potpomognuta postmodernim ekološkim svjetonazorom, a koji naglašava multivokalnost, odnosno vraćanje vrijednosti lokalnim znanjima i strategijama, nastalima u specifičnim kontekstima, zajedno s načelom ravnomjernog prostornog razvitka podrazumijevaju upravo spomenuti razvoj kao zadržavanje $i$ razvijanje posebnosti. Međutim, sve dok integralna održivost, postmoderni ekološki svjetonazor kao i načelo ravnomjernog prostornog razvitka ne budu dio prakse, a ne samo teorijskih razmatranja sociologa i ostalih znanstvenika koji se dotiču tema vezanih uz hrvatske ruralne prostore, moći ćemo, na temelju izvanredne literature, kao što je, svakako, knjiga Antuna Šundalića Selo iz autentičnosti u neprepoznatljivost, samo polemizirati o mogućnostima razvoja hrvatskih sela.

Anita Bušljeta 